\section{Swimming of Monas stigmatica}

RECENTLY it was discovered at Plymouth that Monas stigmatica, E. G. Pringsheim, which is a small flagellate organism with a length of $6 \mu$, was, under the proper conditions, capable of traversing a length of $260 \mu$ in a second. Thus the organism has a relative speed of more than forty, or in other words it traverses forty times its own length in a second, and on this simple calculation the organism has a relative speed which is twice that of the most modern 'Spitfire' and a thousand times that of a modern destroyer.

The principle by which this high speed is attained is that of the rotating inclined plane or the propeller, and since these flagellate organisms represent what is probably the most primitive of all free-swimming organisms it indicates that the principle of the rotating inclined plane or the propeller has existed on the earth ever since living organism first existed near the surface of the ocean, which was probably two or three hundred million years ago. It was not, however, until the year 1842 that the Admiralty owned a steamship driven by a propeller.

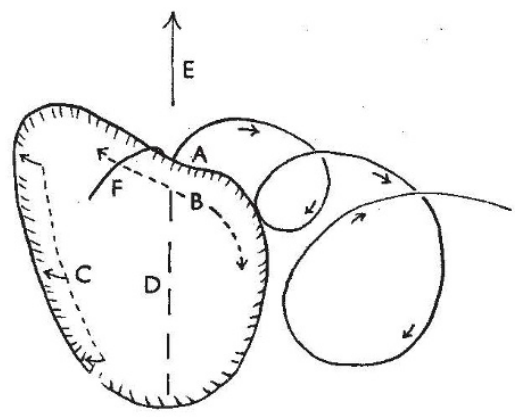

Monas stigmatica with ITS TWo FLAGRLLA. DIAGRAMMatic.

Waves pass along the long flagellum, from base to tip, in a spiral manner with an increase in velocity and amplitude. The force generated is transmitted to the surface of the cell at $A$. This causes the organism to rotate and gyrate about the axis $D$. (The edge $B$ going below the surface of the paper and $C$ being raised above it.) Thus the organism is converted into a rotating inclined plane and moves forward more or less in the direction indicated by the arrow $E$. The very short flagellum $F$ appears to act as a guiding or sensory organ during normal swimming.

'The Laboratory,

A. G. Lowndes.

Citadel Hill, Plymouth.

\section{Porphyrin Formation by Yeast}

IN a recent communication, Rimington ${ }^{1}$ has described his investigations into the formation of porphyrins by autolysing yeast and by yeast press juice, in which he demonstrated an increase in coproporphyrin in a cell-free medium prepared from yeast.

In our experiments we first of all attempted to find conditions under which yeast would produce optimum amounts of porphyrin pigments. To this эnd, fresh top-fermentation brewer's yeast was kllowed to autolyse at $19-22^{\circ} \mathrm{C}$. alone and with the zddition of various substances which were considered possible porphyrin precursors. The best yield of porphyrin was obtained, however, by addition of solid ammonium carbonate to the yeast cells, when a yield of ninety-five times the value from yeast alone was obtained.

TABLE 1. COPROPORPHYRIN FORMEB BX YEAST AFTER ADDITION OF AMmonidu Carbonate.

$450 \mathrm{gm}$. fresh top-fermentation brewer's yeast. Duration of experiment, 96 hours.

\begin{tabular}{|c|c|}
\hline Experiment & $\begin{array}{l}\text { Coproporphyrin } \\
\text { found ( } \mu \mathrm{gm} . / \mathrm{gm} . \\
\text { fresh yeast) }\end{array}$ \\
\hline $\begin{array}{l}\text { Yeast alone } \\
\text { With } 10 \mathrm{gm} .\left(\mathrm{NH}_{3}\right)_{2} \mathrm{CO}_{3} \\
\quad, \quad 10 \mathrm{gm} .\left(\mathrm{NH}_{4}\right) \mathrm{CO}_{3}+2 \mathrm{gm} . \mathrm{KH}_{2} \mathrm{PO}_{4}+ \\
\quad 2 \mathrm{gm} . \mathrm{Na}^{\mathrm{H} \mathrm{PO}_{4}}+ \\
\quad 10 \mathrm{gm} .\left(\mathrm{NH}_{4}\right)_{4} \mathrm{CO}_{3}+30 \mathrm{ml} \text { : amyl } \\
\quad \text { alcohol }\end{array}$ & $\begin{array}{r}0 \cdot 9 \\
85 \cdot 5 \\
59 \cdot 0 \\
43 \cdot 8\end{array}$ \\
\hline
\end{tabular}

When the rate of porphyrin production was studied under these conditions, it was observed that a rapid linear rise until approximately 60 hours was followed by a very sharp fall after 90 hours until porphyrin had almost disappeared from the medium. During the first period, the yeast cells were very active and the disappearance of porphyrin coincided with the onset of true autolysis of the cells.

TABLE 2. RATE OF COPROPORPHYRIN FORMATION BY YEAST AFTER ADDITION OF AMMONIUM CARBONATE.

$250 \mathrm{gm}$. fresh yeast, $5 \mathrm{gm}$. $\left(\mathrm{NH}_{4}\right)_{2} \mathrm{CO}$, added, kept at $19-22^{\circ} \mathrm{C}$.

\begin{tabular}{|c|c|c|c|c|}
\hline \multirow{3}{*}{$\begin{array}{l}\text { Duration of } \\
\text { experiment } \\
\text { (hr.) }\end{array}$} & \multirow{3}{*}{$\begin{array}{l}\text { Coproporphyrin } \\
\text { found ( } \mu \mathrm{gm} \text {./gm. } \\
\text { fresh yeast) }\end{array}$} & \multicolumn{3}{|c|}{$\begin{array}{l}\text { Relative amounts of isomers } \\
\text { present }(\mu \mathrm{gm} . / \mathrm{gm} \text {. yeast })\end{array}$} \\
\hline & & \multirow{2}{*}{ Copro. III } & \multirow{2}{*}{ Copro. I } & Copro. III \\
\hline & & & & Copro. I \\
\hline 0 & $\begin{array}{r}3 \cdot 65 \\
13 \cdot 2\end{array}$ & & & \\
\hline 22 & $27 \cdot 6$ & $0 \cdot 10$ & & 0.008 \\
\hline 43 & $53 \cdot 2$ & $24 \cdot 5$ & 6.6 & $3 \cdot 7$ \\
\hline $66 \cdot 5$ & $56 \cdot 7$ & $34 \cdot 6$ & $3 \cdot 2$ & 10.8 \\
\hline 90.5 & $47 \cdot 0$ & $21 \cdot 2$ & $5 \cdot 80$ & $3 \cdot 66$ \\
\hline 114 & $7 \cdot 1$ & & & \\
\hline $\begin{array}{l}162 \\
186\end{array}$ & $\begin{array}{l}3 \cdot 2 \\
5 \cdot 1\end{array}$ & $1 / 2$ & $2 \cdot 2$ & 0.54 \\
\hline 234 & $19 \cdot 1$ & & & \\
\hline
\end{tabular}

The difference between the total coproporphyrin value and the sum of the two isomers is due to losses incurred in methylation and separation of the pure methyl esters.

When glucose, mannitol and other sugars were added to the yeast, it was observed that with prolonged activity of the yeast the porphyrin content also remained at a high level.

TABLE 3. COPROPORPHYRIN FORMATION BY YEAST AFTER ADDITION OF AMYONIUM CARBONATE AND SUGARS. $250 \mathrm{gm}$. fresh yeast $+\left(\mathrm{NH}_{4}\right)_{2} \mathrm{CO}_{3}+$ sugar.

\begin{tabular}{|c|c|c|c|c|c|c|}
\hline Experiment & \multicolumn{3}{|c|}{$\begin{array}{l}\text { Coproporphyrin } \\
\text { found ( } \mu \text { gm./gm. } \\
\text { fresh yeast) }\end{array}$} & \multicolumn{3}{|c|}{$\begin{array}{l}\text { Relative amounts of iso- } \\
\text { mers present after } 168 \\
\text { hours ( } \mu \text { gm./gm. fresh } \\
\text { yeast) }\end{array}$} \\
\hline $\begin{array}{l}5 \mathrm{gm} \\
\left(\mathrm{NH}_{4}\right)_{2} \mathrm{CO}_{3}+ \\
5 \mathrm{gm} . \\
\text { glucose } \\
5 \text { gm. } \\
\left(\mathrm{NH}_{4}\right)_{2} \mathrm{CO}_{3}+ \\
10 \text { gm. } \\
\text { glucose } \\
4.4 \text { gm. } \\
\left(\mathrm{NH}_{4}\right)_{2} \mathrm{CO}_{3}+ \\
25 \mathrm{gm}+ \\
\text { glucose } \\
5 \text { gm. } \\
\left(\mathrm{NH}_{4}\right)_{2} \mathrm{CO}_{3}+ \\
25 \text { gm. } \\
\text { mannitol }\end{array}$ & $15 \cdot 6$ & $16 \cdot 8$ & $100 \cdot 8$ & $0 \cdot 0$ & $46 \cdot 0$ & 0.02 \\
\hline
\end{tabular}

Brewer's wort $284(72 \mathrm{hr}$. 